\title{
The Journey of Drug Dependents towards Recovery
}

\author{
Jeremike U. Guabong ${ }^{1}$, Devine Grace M. Longno ${ }^{2}$, Khezia Paula C. Castro ${ }^{3}$ and Evangeline M. Guinto ${ }^{4}$ \\ ${ }^{1}$ University of Mindanao, Davao City, Philippines \\ Correspondence: Evangeline M. Guinto, University of Mindanao, Davao City, Philippines
}

Received: November 4, 2015

Accepted: December 23, 2015 Available online: December 24, 2015

doi:10.11114/ijsss.v4i2.1266

URL: http://dx.doi.org/10.11114/ijsss.v4i2.1266

\begin{abstract}
Drug addiction is a worldwide phenomenon which generates problems not only affecting families but the society as well. Addictive substances are rampant among our societies today and minors are easy victims. It is in this premise why the government provides rehabilitation and treatment to this at risk population. The researchers used qualitative case study method to get to know the experiences of the three participants in the rehabilitation agency, the DCTRCDD or Davao City Rehabilitation Center for Drug Dependents. The three participants were using prohibited drugs before admission to the center. The participants shared their journey towards recovery in the agency and because of this, they were able to conceptualize their vision in life and developed values for their welfare and development.
\end{abstract}

Keywords: drug dependents, journey, recovery, Davao City, Philippines

\section{Introduction}

Drug addiction is a worldwide phenomenon which generates problems not only within families but to the society as well. Addictive substances are rampant and accessible leaving the young population easy victims. Addiction can trap anyone. It can lead to harming one's body, causing problems in family structure, and contribute delinquency to society. Treatment enables people to counteract addiction's influential disturbing effects on their brain and behavior and recover control of their lives. Addiction cannot always be cured, but like other chronic diseases, addiction can be managed successfully (National Institute on Drug Abuse, 2014).

\subsection{Purpose of the study}

The study aims to know the experiences of the Davao City Treatment and Rehabilitation Center for Drug Dependents (DCTRCDD) residents toward their recovery. The result of the study gives information to the society about the situation of the residents and the benefits they acquired inside the agency. Moreover, through this study reluctant parents would voluntarily offer their kids to be helped and experience changed lives. Hopefully they will be encouraged to seek help for their kids after reading the testimonies of our participants.

The locale of the study is Davao City Treatment and Rehabilitation Center for Drug Dependents (DCTRCDD). This is a center managed by the Local Government of Davao City. It provides a complete rehabilitation program to clients through the use of varied approaches conducted by a multidisciplinary team. A therapeutic community approach reinforced with spiritual guidance is found effective as espoused by clients and their families (Casas, 2014). In this approach, the clients are like residents of a normal community where they are assigned to various responsibilities and positions to perform.

\section{Method}

This is a Qualitative Case Study. This research method involved an up-close, in-depth, and detailed examination of the experiences of three drug dependents, a female and male minor, and one male adult resident (Denzin \& Lincoln, 1994). Our three participants were chosen from the many residents of the center. They were recommended by the multidisciplinary team because their stories would be able to satisfy what we wanted to explore in this study. We became intimate with the participants as we had our 5 month stay in DCTRCDD as social work interns. Interviews were conducted in a natural fashion. House parents and social workers were also very helpful in providing collateral information. We were surrounded with supportive staff as we conducted this study and we are truly grateful for their guidance. 


\section{Results}

\subsection{The Case of Jay}

Jay is 32 years old, an adult resident of the center. He was voluntarily sent by his family for the reason that he did not continually cooperate with the aftercare program of the government in 2014. He was categorized as recommitted within the same year 2014 .

For the second time around, Jay had undergone rehabilitation. This time, he showed changes gradually. He became God fearing and respectful to his family, especially to his older sister as he is the youngest in their family. He started to cooperate in household chores, gardening and in almost all activities in the center. He also engaged himself to playing basketball and billiard. The staff observed that he is much better adjusted with the life in the center this time.

Despite his efforts to be good, there were times when he was given negative sanctions due to some mistakes. He is approachable but he is not the type of person who makes friends and immediately trusts others according to his social worker.

Jay revealed to us some of his experiences inside the agency like his birthday celebration. It was very meaningful to him because they gathered together as one family unlike before that he just asks money from his parents then hang out with his friends.

\section{"The first time I celebrated birthday with my family was my $30^{\text {th }}$ birthday. It was one of the most wonderful things that happened in my life. I then realized how important I am to my family and I said to myself that "tears of joy" is indeed true. It also made me realize the undesirable things I had done before"}

While listening to him, we were carried away by his childlike happiness. His sharing was honest and pure but the euphoria was over when he shifted to the bad memories in the center. It was when he was placed at the OR (Observation Room). To him it was really unforgettable because he celebrated his $31^{\text {st }}$ birthday there in contrast to his $30^{\text {th }}$ birthday. This came about because his co- residents did not do their respective assignments inside the dormitory. He got so angry to the point that he disobeyed the structured activities. Staying in the OR was the consequence of his misbehavior. It lasted even until his $31^{\text {st }}$ birthday. He recalled how he appealed to the staff to be allowed to spend birthday with his family but it was denied.

\subsection{Thoughts and feelings about the intervention inside DCTRCDD}

Despite the bad times, he still considers the staff interventions as helpful and reasonable. For him, every activity helped him towards recovery and transformed him to be a good person. He promised to keep those experiences until his discharge from the center. These are things that he never experienced with his family because he was pampered. $\mathrm{He}$ could resort to a lot of gimmicks just to get what he wants. But in the center, a policy is a policy. No buts or ifs. When it is black, then it is black. There are no favorites in the center. If you misbehave, there is a consequence.

"I am happy because I was able to surpass my problems. I am convinced that if you are willing to help yourself, you can surpass all your problems. I am also happy that I learned a new character, I learned how to manage my anger. My trust in the Lord also deepened."

When we asked Jay about his insights that during his journey in the agency. He answered that,

"I learned how to listen and respect the opinion of other people unlike before. I also learned how to be humble especially during trying times because if you nurture your pride, it would never be helpful. I also learned how to resist temptations and never entertain in your mind things that would lead you back to vices."

\subsection{The Case of Joy}

Joy is 15 years old and the eldest of five siblings. Based from her records, she has been a good sister to them. Her parents got no regular jobs and because of that she had to stop attending school. She worked to help feed her family. At 14 years old, she was able to work in a small restaurant where she was paid 75 pesos per day. She transferred to another restaurant and got a higher pay of 100 pesos per day. There she was exposed to drugs because according to her, customers openly place drugs on top of their table. Joy was persuaded by her friends to sell illicit drugs for money. It started that way until she also became a user.

Joy was caught in the buy bust operation of the police that was why she was brought to the center. Her psychological test revealed that she have a high level of hostility. She easily gets irritated even with slight provocation. She is also unfriendly, hard to please and was very strict.

After nine months staying in the agency, it was observed that Joy improved a lot. Joy acknowledges her capabilities in 
varied aspects like cooking, dancing and as a leader. Besides, according to her house parent, she was given a task as the chief of the female dormitory because of having good performance, a VS mark which means Very Satisfactory.

As we talked to Joy and asked about her nice experiences inside the agency she replied with pride that: " the best thing that happened to me in the center was when I was chosen as one of the candidates for the Beauty Pageant and got the 1 st runner- up title".

That activity somehow boosted her self-confidence. She may not have experienced being a contestant during her childhood but in the center, her potentials were recognized. She also emphasized that the morning meeting in the center became memorable to her. The morning meeting taught her to become honest to herself and to others. She also learned how to accept feedbacks, advices and comments from her co-wards. Discussions like this developed belonging and camaraderie which she has not experienced from her family.

On the other hand, what she considered as bad experiences were:

"The things that I considered as bad memories in the center are the following: The first one was when I had conflict or misunderstanding with my co-residents wherein it caused trouble to all of us. We were so affected with that disagreement. Second, was when I had quarrel with my house parent then she confronted me and frankly told me that I am strict".

Later, Joy explained that the pain was necessary in order to learn. As she looked back, she was able to reflect that those were very helpful for her because she is now aware of the things that she is unconscious before. She also emphasized that those activities and programs provided by the agency developed her positively and made her realize the wrong decisions she made before.

In addition, she expressed that she is happy and fortunate because she was able to attend those activities or programs. She was also inspired to change because of the testimonies of those who were in agency before and became successful in their lives. It is never too late, according to her.

Joy also developed values and realized that in facing life challenges she really needs to be strong and should never give-up. She has become matured enough in facing her problems. Furthermore, she also developed empathy and patience in relating with other people. The value of respect is now clear to her. Most of all, she learned that she should really think before deciding anything so that she could not commit major mistakes that will make her regret the rest of her life.

\subsection{The Case of Vince}

Vince is 16 years old, an only son. He was detained together with his father at the police station for three days but transferred eventually to the rehabilitation center. Vince was caught together with his father during the raid at his father's home. Vince had been staying in the center for more than 5 months. The client is a silent type of person, he's tall, dark and dignified, and he also answers directly. While he was in the agency, he learned how to pray, do the laundry, wake up early and clean the house. He disclosed that he never did these kind of chores while he was still outside. Vince was assigned to be the expediter for the minor's dormitory. The expediter's role is to lead the group, call the roll, gather the group during activities and check the orderliness of the dorm. He revealed during the interview that his mother is his inspiration to change. He realized that in our day-to-day lives we experience a lot of battles, struggles, trial and learnings. We may stumble and fall but we still learn how to stand and fight.

As we started asking Vince about his battles, trials and learning inside the agency he answered that the best thing that he experienced in the agency was during the holy week. It was unforgettable for him since it was his first time to join a recollection. It was an opportunity for him to repent and ask forgiveness. He was so moved by that close encounter with his Creator.

"This is really the new me"

On the contrary, he doesn't like it when he encounter misunderstanding with his co-residents. Most of the time he just shrug it off and do not mind them even if sometimes they laugh at him. He had to be patient and keep the bitterness inside because he is here to change himself he said. He tried to understand them because he knew they have different attitudes and stories.

He also commented that he feels bored with the activities because it is customary. It activates his stress because it is structural although he also claimed it helps him and he learned a lot from it. The rosary that they recite every night was also customary but he likes it. He especially mentioned Saturday afternoon as very exciting for him and his co-residents because it breaks the monotony. They experience a kind of variety show every Saturday that is why he looks forward to it. It is like TGIS or Thanks God Its Saturday.

I felt happy I was able to experience a new environment. The CBP or character building program really helped 
me. It changed the whole lot in me. It is really different if you take things heartily because it would have lasting effects and no one can take it away from you".

He intimated how touched he was for those co-residents who are not visited by friends and family. Nobody takes care of their personal needs. With these, he learned how to be generous and he feels real happiness. As if he empties himself yet there was joy. It helped him a lot to forget his problems for the mean time. It helped him gain self-confidence and he was able to do the things he had never done before. He related to us what he learned most:

"Being generous because there were times when some of my co-residents were not visited by their family and they do not have supplies (basic needs). I also learned to be patient because there are instances which are beyond our control. It became normal already that we have misunderstandings and sometimes, it leads to violent actions. I also learned acceptance. I have to accept that there are problems that cannot be solved quickly. Most of all, I learned to be careful in relating with others. I am cautious on what to ask from others because I might not like their responses although I also learned that individuals have different perspectives and attitudes. I need to think and weigh things before making decisions. I promised to put into practice what I learned and experienced in the agency".

He said sometimes all the staff only noticed their mistakes even though they tried hard to cope with the expectations of their surroundings and other people think that they are just pretending as reformed person. Vince swear that he is doing the right thing even if no one is watching to prove to them that they are wrong of their impressions. He also said that he is now able to extend his patience.

\section{Discussion}

The road to recovery is not easy. Drug dependents wanting to be rehabilitated has to convince themselves that they can make it. This is true to Jay, Joy and Vince. By the time they wholeheartedly cooperate with the center staff, they started their journey to recovery. The internal is decisive while the external can only facilitate and hasten change that they want in their lives. Jay, Joy and Vince are the internal while the center staff and peers are external factors.

Seasoned house parents in the center affirmed that disagreement among residents is very common problem inside the agency considering that they are troubled that is why they came to the center. They have complex problems within themselves and their families thus clashes is normally expected. Residents experience triggers and these are considered part of their development on how to deal with it. House parents are around to sit with them and process their feelings for positive resolution of conflicts.

Residents in this therapeutic community who are actively involved in the dynamic recovery process would really experience behavioral changes and even changes in their outlook on life (Smith D., 2012). As revealed by the three participants, the community based approach was useful in helping them change their personal perspective and develop positive values. The best experiences as disclosed by the participants were necessary motivating factors that let them realize that life can be beautiful. Those experiences made an imprint because they have not experienced it outside that was why they thought drugs could compensate. Now they realized a happy and meaningful life can be realized without drugs.

For Jay, it was a simple birthday with his family. The wonderful feeling was beyond compare, the feeling of being wanted and loved by his family. For Joy it was the recognition of her inner qualities in the center which were invisible to the eye before. The metamorphosis happened in the center and this is what she waited for. For Vince, it was a close encounter with the Creator, a very spiritual one. He was not able to experience this before thus the feeling of lethargy, hopelessness and dependence to drugs.

People who are in drug or alcohol use can cause them to experience problems. They do not understand themselves especially if they have other emotional issues. They really need professional help to change themselves (Wilson \& Kolander, 2003). That was what they thought but later they realize that they have to decide for themselves. Their decision to change despite the pain, the humiliation, and the sacrifices they endure like the sanctions inside the center were actually what made them recover. The interventions provided by the agency were just facilitating forces. Because they endured, they accepted and remolded themselves they are on the road to recovery.

\subsection{Thoughts regarding the interventions}

At first it was normal for them to resist a completely different life in the center but later on, as they cooperated, as they allowed themselves to undergo struggles and pain, they realize that those interventions were really helpful and beneficial for their growth and development. The participants were honest to express that some activities were stressful but it provided fruitful effects to them.

Treatment conducted by mental health professionals produced encouraging result. Even if most treatments were just 
brief, it was found out that those who remained in treatment longer had the best outcomes. The longer they stayed in the center the more convinced they became that an improved life is attainable.

\subsection{Feelings regarding the interventions}

Out of the intervention provided by the agency, the three participants expressed that they are happy because they gain benefits from it. Those benefits were having a stronger faith in God and learn new characters. Joy added that she was also inspired to change due to the testimonies of other residents who finished the rehabilitation program and was able to have full recovery.

After attending the program it was discovered that all of the participants of this study experienced a number of positive changes in their relationships with their family members and partners (Schäfer, 2013). The positive effects experienced by the participants resulted to positive feeling and emotion. According to one of the house parents, the residents will feel great if there will be activities outside the center. And in attending the activities, one of the qualifications is having very satisfactory performance. This would identify the residents who were able to join the activity. Because of this, some of the residents are not happy. Also they will be encouraged to have good performance so that they could attend activities that will be conducted outside the agency.

\subsection{Learning Insights}

The participants were able to obtain wisdom from their experiences and daily living within the agency. The participants pronounced that they were able to learn patience towards others. They also value the advices not only from agency staff but also from their co-residents. Besides, they tried to apply such advices in their recent life. One of the residents also claims that he learned to give because he can observe that some of his co-residents lack family support.

In relation, the integration of strength perspective with the idea self-efficacy is effective in helping a person with the substance dependence to restore the degree of his or her self-worth and sense of achievement. Part of this is the intervention that is considered as the harm reduction model that was integrated into the practice and the well-being of the client (Kerr and Gibson, 2009). Due to the impaired dignity of the person who use illicit drugs it is necessary that they would be helped to develop positive self-efficacy through the use of their strength as individual rather than their weakness.

\subsection{Implication for Practice}

Drug addiction is disease that can and must be treated through the willingness and self-determination exerted by the drug dependent. Hopeless individuals were trans-formed into the realization that recovery could be achieved and that life could be better. Each journey was, of course, a personal one, but the presence of others was necessary (Hansen, Ganley \& Carlucci, 2008). Because of this transformation is possible through full support of the significant others and the treatment provided by the experts working in institution treating drug addiction. The social learning theory of Albert Bandura (1977) reminds us that changes in human behavior comes from interaction between cognitive, behavioral and environmental influences. There must be processes of attention, acquisition and retention into memory so that those changes would be instituted in the person (McLeod, 2011). Because of the experiences of the residents they were able to learn new lessons and values that help to facilitate their treatment. This also motivated them to develop positive behavior that leads them to a better performance in life.

According to the New Hope Recovery Center (2013), recovered drug addicts learn to avoid things, people or situations that will lead them back to using drugs. Through daily associations such as waking up in the morning and praying or meditating, they would successfully resist temptations. And finally, they learn socially acceptable behavior from multidisciplinary mentors, family and friends. It further implies that the journey of drug dependents towards recovery is possible through the varied task and responsibilities they perform. Any therapeutic center would be helpful in providing opportunities where they would be able to learn and experience things that can facilitate their recovery.

Individuals who are dependent on drugs has the boundless possibility to change despite enormous struggles. Change will occur through their willingness and self-determination to change. Institutions and experts providing treatment are aids in their transformation and without the full support of significant others, especially their families, recovery is impossible. There are also those who believe that to achieve full recovery, they have to strengthen their relationship with their Creator.

The result of this study implies the need for the treatment providers specially the social workers to acknowledge the capabilities of the drug dependents to change through empowerment. As treatment providers they are primarily tasked together with a multidisciplinary team to facilitate the recovery of drug addicts. They have to get the trust of the clients during the treatment process and after an extended treatment, they are expected to fully motivate the clients to go through recovery (Brien, 2014). 
Social Workers and those in the helping profession cannot just limit one sure solution to recovery. It has to be a combination of various approaches but the most important thing is the self-determination of the person to change and attain quality of life. Social workers in rehabilitation centers play an important role in motivating people to face challenges and enable them to take action to combat drug addiction (Brody S., 2010). This study hopes to inspire social workers in drug rehabilitation centers to continuously improve the therapeutic modalities and widen the road to recovery.

\section{Acknowledgment}

The internship program and this research project would not have been successful without the help and guidance of the persons worthy of special mention:

The Davao City Treatment and Rehabilitation Center (DCTRCDD) center head, Dr. Gene Gulanes, the Social Workers, especially Ma'am Perla Redulosa, our Agency Field Instructress, the Staff, residents and house parents; Jay, Joy and Vince who contributed their life story for the completion of this study, thank you for everything. This study will not be realized without you.

To the University of Mindanao administration, faculty and staff, thank you for believing in us and providing us the transformative education.

We are very fortunate to have our families, especially our parents who are always ready to guide us in times of difficulties. Thank you for providing us the financial support and for the unconditional love. We are very blessed to have you and to be with you.

Finally, to our Almighty God and Father, we are very thankful for the strength and knowledge that you have given us in making this study a successful one. We thank you for giving those special persons in our life who served as our strength in every challenge we have encountered and as our inspiration in pursuing this study. Most of all thank you for the undying guidance and blessings that we ever received from you. "Commit to the Lord whatever you do and he will establish your plans. Prov.16:3"6:3"

\section{References}

Brien C., (2014). The journey of recovery from addiction: A report evaluating the service provided via the secondary treatment programs of Tabor Lodge Addiction and Housing Services Limited. Retrieved on November 15, 2015 from https://www.ucc.ie/en/media/research/carl/2014_CarmelOBrien.pdf

Brody S. (2010). What is the role of social workers? Retrieved on November 19, 2015 from http://www.communitycare.co.uk/2010/09/20/what-is-the-role-of-social-workers/

Casas A. (2014). Treating Drug Dependents. Retrieved on August 3, 2015 from http://archive.sunstar.com.ph/davao/local-news/2014/02/07/treating-drug-dependents-327110

Denzin, N. K., \& Lincoln, Y. S. (1984). Handbook of Qualitative Research, Newbury Park: Sage Publications

Hansen M., Ganley B., \& Carlucci C. (2008). Journeys from addiction to recovery. Retrieved on September 14, 2015 from http://www.academia.edu/6443662/Journeys_From_Addiction_to_Recovery

Kerr, E., \& Gibson, O. (2009). Substance Abuse New Research. Nova Science Publisher. Inc. p. 168-169

McLeod S. (2011). Bandura - Social Learning Theory. Retrieved on November 17, 2015 from file:///E:/\%C2\%A0/Albert\%20Bandura\%20_\%20Social\%20Learning\%20Theory\%20_\%20Simply\%20Psychology .html

National Institute on drug abuse, (2014). Retrieved on August 5, 2015 from http://www.drugabuse.gov/publications/drugs-brains-behavior-science-addiction/treatment-recovery

New Hope Recovery Center (2013). Addiction and Learning Theory. Retrieved on September 20, 2015 from http://www.new-hope-recovery.com/center/2014/04/02/addiction-learning-theory/

Schäfer, G. (2013). Multiple Family Group Therapy in a Drug and Alcohol Rehabilitation Centre: Residents' Experiences. Retrieved on June 20 from http://onlinelibrary.wiley.com/doi/10.1375/anft.29.2.88/abstract

Smith D. (2012). Alcohol, Drug, Well-being and Recovery in New Zealand. Retrieved on November 06, 2015 form http://mro.massey.ac.nz/bitstream/handle/10179/3759/02_whole.pdf?sequence=1

Wilson, R., \& Kolander C. (2003). Drug Abuse Prevention: Second Edition. Jones and Bartlett Publisher Inc.

\section{(cc) $\mathrm{Br}$}

This work is licensed under a Creative Commons Attribution 3.0 License. 